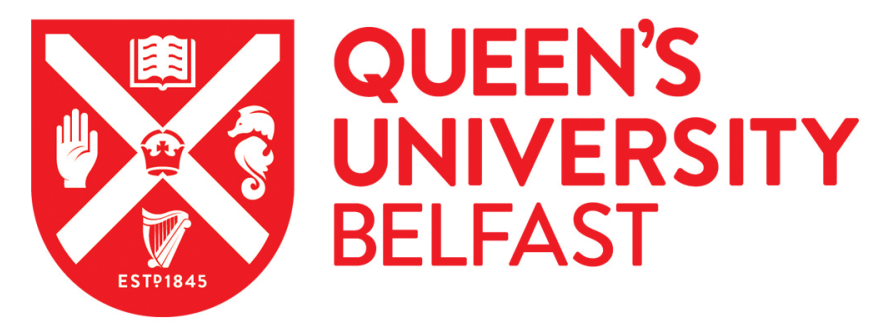

\title{
The role of arbuscular mycorrhizal fungi in the transfer of nutrients between white clover and perennial ryegrass
}

Rogers, J. B., Laidlaw, A. S., \& Christie, P. (2001). The role of arbuscular mycorrhizal fungi in the transfer of nutrients between white clover and perennial ryegrass. Chemosphere, 42, 153-159.

Published in:

Chemosphere

Queen's University Belfast - Research Portal:

Link to publication record in Queen's University Belfast Research Portal

\section{General rights}

Copyright for the publications made accessible via the Queen's University Belfast Research Portal is retained by the author(s) and / or other copyright owners and it is a condition of accessing these publications that users recognise and abide by the legal requirements associated with these rights.

Take down policy

The Research Portal is Queen's institutional repository that provides access to Queen's research output. Every effort has been made to ensure that content in the Research Portal does not infringe any person's rights, or applicable UK laws. If you discover content in the Research Portal that you believe breaches copyright or violates any law, please contact openaccess@qub.ac.uk. 


\title{
The role of arbuscular mycorrhizal fungi in the transfer of nutrients between white clover and perennial ryegrass
}

\author{
Jacqueline B. Rogers ${ }^{\mathrm{a}, 1}$, A. Scott Laidlaw ${ }^{\mathrm{a}, *}$, Peter Christie ${ }^{\mathrm{b}}$ \\ a Department of Applied Plant Science, The Queen's University of Belfast, Newforge Lane, Belfast BT9 5PX, UK \\ ${ }^{\mathrm{b}}$ Department of Agricultural and Environmental Science, The Queen's University of Belfast, Newforge Lane, Belfast BT9 $5 P X$, UK
}

\begin{abstract}
A glasshouse experiment was conducted in which ${ }^{15} \mathrm{~N}$ was used as a tracer applied as $\left({ }^{15} \mathrm{NH}_{4}\right)_{2} \mathrm{SO}_{4}$ to donor plants of white clover and perennial ryegrass. Nitrogen transfer via hyphae of arbuscular mycorrhizal fungi (AMF) or by other routes was studied by separating the root systems of the two plant species, as donors and receivers, when growing in the same pot, with selective mesh barriers of varying pore sizes in the presence and absence of AMF. Inoculation with AMF increased DM production and nitrogen $(\mathrm{N})$ yield of clover plants. Transfer of ${ }^{15} \mathrm{~N}$ occurred between white clover and grass plants but was independent of AMF. Pore size of the mesh barriers controlled the degree of ${ }^{15} \mathrm{~N}$ enrichment in the grass, suggesting that transfer was mediated by mass flow and/or diffusion. Additional experiments showed that grass roots could pass through pores of $60-\mu \mathrm{m}$ diameter, and hyphal links could not be detected by autoradiography, thus supporting the conclusions of the tracer experiment. (c) 2000 Elsevier Science Ltd. All rights reserved.
\end{abstract}

Keywords: Arbuscular mycorrhiza; Nitrogen transfer; White clover; Perennial ryegrass

\section{Introduction}

Proposed routes for the transfer of nutrients, especially nitrogen $(\mathrm{N})$, from legume to associated grass include death and decay of nodules and roots (Butler et al., 1959; Dubach and Russelle, 1994), exudation from legume roots (Ta et al., 1986) or by hyphal links formed by arbuscular mycorrhizal fungi (AMF) between legume and grass roots (Haystead et al., 1988). It is generally acknowledged that in grass/white clover associations turnover of $\mathrm{N}$ in roots, nodules and stolons is the major source of transferable $\mathrm{N}$ (Laidlaw et al., 1996) but the evidence for hyphae-mediated transfer of $\mathrm{N}$ between

\footnotetext{
${ }^{*}$ Corresponding author.

E-mail address: scott.laidlaw@dardni.gov.uk (A. Scott Laidlaw).

${ }^{1}$ Present Address. School of Environmental Management and Geography, University of the West of England, Frenchay Campus, Coldharbour Lane, Bristol BS16 1QY, UK.
}

legumes and grass is conflicting (Haystead et al., 1988; Barea et al., 1989; Frey and Schüepp, 1993; Ikram et al., 1994).

The strongest evidence for the positive role of $\mathrm{N}$ transfer by AMF from white clover to grass has been presented by Haystead et al. (1988) using a split root technique to label $\mathrm{N}$ in white clover. They compared the amount of $\mathrm{N}$ transferred to grass sharing the part of the clover root system fed from the remainder of the root system in an adjacent pot in the presence and absence of AMF. Roots in the shared pot were separated by barriers of mesh, the pore sizes of which were considered to allow solute diffusion and mass flow $(3 \mu \mathrm{m})$, hyphae to pass through $(60 \mu \mathrm{m})$, or the roots were completely separated by solid barriers or allowed to interact unhindered. Preliminary studies with mesh barriers of varying pore size indicated that $60 \mu \mathrm{m}$ would allow roots to penetrate (Rogers, 1993) and so raised the possibility that the effect found by Haystead et al., may have been due to grass roots penetrating the mesh and exploring the $\mathrm{N}$-rich rhizosphere in the clover compartment. 
Rogers (1993) also found that a mesh with pore size of $5 \mu \mathrm{m}$ was sufficiently small to prevent passage of external AMF hyphae. The present study was undertaken to investigate the effectiveness of barriers of varying mesh sizes in limiting $\mathrm{N}$ transfer and to re-evaluate the evidence regarding the role of AMF in forming effective hyphal links between perennial ryegrass and white clover.

\section{Materials and methods}

\subsection{Experiment 1. The role of $A M F$ in the transfer of nitrogen from white clover to perennial ryegrass}

The method of Haystead et al. (1988) outlined briefly above was followed with some modifications. In the split root assemblages, the barrier used to separate the root systems of the ${ }^{15} \mathrm{~N}$-fed donor and the receiver comprised nylon mesh of pore dimensions 5,15 or $60 \mu \mathrm{m}$ in addition to a complete barrier and no barrier.

Inoculum comprised heavily mycorrhizal root fragments and adhering soil from grass/white clover plots in an experiment already described (Laidlaw et al., 1996). The inoculum was mixed thoroughly with the sterilised soil/sand mixture in the appropriate treatments and a pad of infected roots was also inserted below the roots of transplanted seedlings.

Each assemblage consisted of two pots. All pots $\left(15 \times 15 \mathrm{~cm}^{2}\right)$ were filled with three parts autoclaved acid-washed builder's sand: one part $\gamma$-irradiated (1 Mrad) loam soil from the A horizon of a permanent pasture and the experiment comprised 60 assemblages. The experimental design was three replicated blocks of the five barrier treatments with or without inoculum and with grass or clover as the 'receiver'. One of the pots in each assemblage contained half of the root system of each pair of donor plants to which ${ }^{15} \mathrm{~N}$ was applied, while the other contained the other half of the root system of the donor plants and that of the pair of receiver plants, separated from the donor roots unless barrierless. The mesh barriers were glued to $1-\mathrm{mm}$ thick PVC frames, which in turn were affixed to the pots with plastic cement and sealed with a self-curing non-toxic rubber sealant. The complete barrier was positioned with sealant only which was subsequently found to be inadequate and the effectiveness of the complete barrier broke down.

Plants were grown in a slightly heated glasshouse (daytime maximum in the absence of sunlight was $15^{\circ} \mathrm{C}$ ) and natural light was supplemented with mercury vapour lamps supplying $150-400 \mu \mathrm{mol} \mathrm{m}^{-2} \mathrm{~s}^{-1}$ for $12 \mathrm{~h}$ per day. $50 \mathrm{ml} 25 \%$ full strength nutrient solution was applied weekly and $50 \mathrm{ml}$ distilled water was applied daily to each pot containing roots of both species. Three weeks after setting up the experiment, $3.5 \mathrm{mg}$ $\left({ }^{15} \mathrm{NH}_{4}\right)_{2} \mathrm{SO}_{4}$ at 99.7 at. $\%$ excess was applied in solution every 2-3 days to the pot in each assemblage which contained half of the donor root systems. A total of 124 $\mathrm{mg} \mathrm{N}$ per pot was supplied. 11 applications were made before the first harvest, 16 between the first and second harvests and 8 between the second and third. Donor and receiver plants were harvested to $2 \mathrm{~cm}$ above soil level 7 , 12 and 18 weeks after planting. After 26 weeks donor shoots were harvested to ground level while receivers were harvested to $2 \mathrm{~cm}$. Receiver shoots and roots were destructively sampled after a further four weeks.

The proportion of length of roots infected with AMF was assessed in samples of roots of receiver plants which were cleared and stained at the end of the experiment using a modification of the procedure of Phillips and Hayman (1970). The proportion was estimated using a grid-line intersection method from presence or absence of infection in roots at 200 intersections using 50 root segments per sample. Harvested herbage was dried at $60^{\circ} \mathrm{C}$, milled and passed through a $280-\mu \mathrm{m}$ sieve and analysed for total $\mathrm{N}$ and ${ }^{15} \mathrm{~N}$ with a Europa Scientific ANCA/MS.

\subsection{Experiment 2. To investigate the ability of grass and clover roots to penetrate mesh with pores of different diameters}

14-day-old seedlings of white clover (cv Huia) and perennial ryegrass (cv Talbot), germinated on moist filter paper, were transplanted into 9-cm Petri dishes to provide a confined space to encourage penetration of the roots through the mesh of given pore size which lined the Petri dishes. Each dish had drainage holes on the base and was lined with a disc (diameter $11 \mathrm{~cm}$ ) of 60, 35,15 or $5 \mu \mathrm{m}$ nylon mesh. The disc allowed the base and sides of the dish to be lined with a $2.5-\mathrm{mm}$ lip around the top of the dish. The base of the dish was filled with a 1:1 (v/v) sand:soil mixture. The seedling was planted in the growth medium and the shoot was threaded through a hole of approximately $3-\mathrm{mm}$ diameter cut in the centre of the lid of the dish. The lid was sealed to the base with insulating tape. 12 replicates were set up for each mesh size. The seedlings in the Petri dishes were arranged on plastic trays and placed in a growth cabinet at $20^{\circ} \mathrm{C}$ constant temperature set at a 16-h daylength and $90 \%$ humidity. $25 \mathrm{ml}$ water and $10 \mathrm{ml}$ of four-fold nutrient solution (Dart and Pate, 1959) were applied to the trays daily, ensuring that nutrients were always available within the Petri dishes.

Six of the replicates were examined under a dissecting microscope for penetration of the mesh by seedling roots after five weeks growth in the cabinet and the remaining six replicates were examined after a further four weeks. In instances where roots had penetrated, their length and diameter and presence or absence of branches was recorded. 
2.3. Experiment 3. To investigate the possibility of transfer of carbon between roots of mycorrhizal perennial ryegrass and white clover using ${ }^{14} \mathrm{C}$ autoradiography

Perennial ryegrass (cv Talbot) and white clover (cv Huia) seedlings were grown in a glasshouse (conditions similar to Experiment 1) in seed trays, grass for six weeks and clover for 8 weeks, in a sterilised sand:soil mixture either inoculated with AM fungi by mixing with colonised root fragments and AMF spores or uninoculated. Root washings were applied to the latter in an attempt to ensure microbial populations (other than mycorrhizal fungi) were similar in both media. 100-ml quarter strength nutrient solution was applied weekly and $100 \mathrm{ml}$ distilled water twice weekly. After 6 weeks the grass and clover roots were $30-45 \%$ and $50-70 \%$ mycorrhizal, respectively.

One clover and one grass plant, either mycorrhizal or non-mycorrhizal, were transplanted as a pair in factorial combination into specially adapted 9-cm diameter Petri dishes filled with sterilised sand comprising particles of $0.8-1.0 \mathrm{~mm}$. Three holes of $5 \mathrm{~mm}$ diameter were drilled in the lid of each dish, one at one quarter along a diameter line, one in the centre and one three quarters along the same line. A plant was transplanted in the dish at the site of each of the two outer holes and water and nutrients were applied through the central hole. Each dish received $10 \mathrm{ml}$ water twice weekly and $10 \mathrm{ml}$ quarter strength nutrient solution once per week. After 4 weeks the lids of the dishes were sealed to the base with Terostat.

Shoots of the clover plants were enclosed in a cellophane bag that had a 1-cm square rubber septum sealed on its surface. This allowed labelled salt solution and acid to generate ${ }^{14} \mathrm{C}$ to be introduced inside the bag into a $10 \mathrm{ml}$ glass vial which had been placed on the lid of the Petri dish before the bag covered the clover shoots. ${ }^{14} \mathrm{CO}_{2}$ was generated by adding excess concentrated lactic acid to calcium carbonate $\mathrm{Ca}^{14} \mathrm{CO}_{3}$. This was calculated to expose the clover to $25 \mu \mathrm{Ci}$ of ${ }^{14} \mathrm{CO}_{2}$. After $36 \mathrm{~h}$ of exposure, clover shoots were excised and the root systems prepared for autoradiography by washing soil from the roots in a fine jet of water but minimising disturbance by retaining the root system in the Petri dish. The root systems were photographed at $40 \times$ magnification through the transparent dish base before being gently removed from the dish, blotted dry and placed on autoradiographic paper and sealed within a wooden cassette for $24 \mathrm{~h}$. Photographs and autoradiographs were compared to identify the organs which had ${ }^{14} \mathrm{C}$ in the developed autoradiographic plates.

\section{Results}

Due to the breakdown of the seams around the solid barrier, the 'total barrier' treatment was an inadequate control and is not considered further. The $5-\mu \mathrm{m}$ barrier is therefore taken as the treatment representing minimum rhizosphere interaction.

Mean infection rate for roots of grass (based on root length infected) was $27.6 \%$ for inoculated and $0 \%$ for uninoculated treatments compared to $35.6 \%$ and $1.2 \%$ for corresponding infection rates for clover (Table 1). AMF inoculation had little effect on $\mathrm{N}$ content and DM yield of grass donor plants but significantly increased $\mathrm{N}$ content and DM yield of white clover shoots from harvest 2 and ${ }^{15} \mathrm{~N}$ enrichment of $\mathrm{N}$ in clover donor shoots was significantly reduced due to AMF inoculation. Inoculation significantly increased clover receiver shoot DM yield at three of the five harvests but had no effect on grass receiver DM yield (data not presented). Nitrogen content of clover receiver shoots was significantly increased by inoculation at harvests 2 and 4 but grass receiver shoots were unaffected by inoculation. Inoculation did not affect ${ }^{15} \mathrm{~N}$ enrichment of grass or clover receiver shoots (Table 2).

Mean shoot DM yield of clover receiver plants was lower than grass shoots at the first harvest but higher than grass at harvests 3, 4 and 5 (Table 3). Barrier type interacted with species at harvest 1 due to grass shoot DM being lower in the $5 \mu \mathrm{m}$ mesh treatment than in the other treatments (except $15 \mu \mathrm{m}$ ), and at harvest 4 caused by DM yield of clover shoots being lower in the $60 \mu \mathrm{m}$ treatments than the other barrier types. Clover receiver shoots had consistently higher $\mathrm{N}$ content than those of grass but $\mathrm{N}$ content was not affected by barrier type (Table 4). Except for harvest 1, clover receiver shoots had significantly lower enrichment than grass receiver shoots. From harvest 3 onwards, enrichment of grass shoots was increased with increasing mesh pore size (Table 5).

A mesh of pore size $35 \mu \mathrm{m}$ allowed a few grass roots to penetrate, although the mean length of roots which breached the barriers was less than those which penetrated a $60 \mu \mathrm{m}$ pore size (Table 6). With both of these mesh sizes, the mean width of the root at the other side

Table 1

Experiment 1: percentage of root length of receiver plants colonised by AM fungi at the end of the experiment

\begin{tabular}{llcc}
\hline Barrier $(\mu \mathrm{m})$ & Inoculum & Grass & Clover \\
\hline Total & + & 30 & 42 \\
& - & 0 & 2 \\
5 & + & 27 & 38 \\
\multirow{5}{*}{15} & - & 0 & 1 \\
& + & 33 & 32 \\
60 & - & 0 & 0 \\
\multirow{2}{*}{ No barrier } & + & 22 & 43 \\
& - & 0 & 3 \\
& - & 26 & 23 \\
& & 0 & 0 \\
\hline
\end{tabular}


Table 2

Experiment 1: $\mathrm{N}$ content $\left(\mathrm{g} \mathrm{kg}^{-1}\right)$ and at.\% excess in herbage in inoculation treatments (mean of barrier treatments) in receiver plant shoots

\begin{tabular}{|c|c|c|c|c|c|c|}
\hline Harvest & Receiver & Inoculum & $\mathrm{N}$ content $\left(\mathrm{g} \mathrm{kg}^{-1}\right)$ & SEM & at. $\%{ }^{15} \mathrm{~N}$ excess & SEM \\
\hline \multirow[t]{4}{*}{1} & Clover & + & 25.9 & & 2.49 & \\
\hline & & - & 21.5 & $1.91 \mathrm{~ns}$ & 3.88 & $0.35 \mathrm{~ns}$ \\
\hline & Grass & + & 15.7 & & 1.85 & \\
\hline & & - & 13.4 & $1.91 \mathrm{~ns}$ & 1.41 & $0.35 \mathrm{~ns}$ \\
\hline \multirow[t]{4}{*}{2} & Clover & + & 39.5 & & 0.07 & \\
\hline & & - & 35.6 & $0.98^{*}$ & 0.11 & $0.11 \mathrm{~ns}$ \\
\hline & Grass & + & 15.3 & & 0.21 & \\
\hline & & - & 14.3 & $0.98 \mathrm{~ns}$ & 0.50 & $0.11 \mathrm{~ns}$ \\
\hline \multirow[t]{4}{*}{3} & Clover & + & 39.4 & & 0.11 & \\
\hline & & - & 36.8 & $0.57 \mathrm{~ns}$ & 0.08 & $0.09 \mathrm{~ns}$ \\
\hline & Grass & + & 17.5 & & 0.70 & \\
\hline & & - & 15.9 & $0.57 \mathrm{~ns}$ & 0.55 & $0.09 \mathrm{~ns}$ \\
\hline \multirow[t]{4}{*}{4} & Clover & + & 34.2 & & 0.02 & \\
\hline & & - & 28.0 & $0.58^{*}$ & 0.03 & $0.08 \mathrm{~ns}$ \\
\hline & Grass & + & 12.7 & & 1.01 & \\
\hline & & - & 12.0 & $0.58 \mathrm{~ns}$ & 0.82 & $0.08 \mathrm{~ns}$ \\
\hline \multirow[t]{4}{*}{5} & Clover & + & 24.6 & & 0.11 & \\
\hline & & - & 21.1 & $0.99 \mathrm{~ns}$ & 0.14 & $0.05 \mathrm{~ns}$ \\
\hline & Grass & + & 18.4 & & 1.18 & \\
\hline & & - & 17.1 & $0.99 \mathrm{~ns}$ & 1.38 & $0.05 \mathrm{~ns}$ \\
\hline
\end{tabular}

of the barrier from the plant was about twice that of the size of the pores. Clover roots were incapable of penetrating any of the barriers but root hairs were apparent at the other side of the barrier from the plant in barriers of 35 and $60 \mu \mathrm{m}$ pore size.

In Experiment 3, ${ }^{14} \mathrm{C}$ was detected in roots and shoots of white clover. Some roots of grass also contained ${ }^{14} \mathrm{C}$. Although AMF hyphae could be seen, no hyphal links were apparent in the autoradiographs.

\section{Discussion}

Although mycorrhizal clover had a higher $\mathrm{N}$ yield and lower ${ }^{15} \mathrm{~N}$ at. $\%$ excess enrichment than nonmycorrhizal clover, AMF infection did not appear to increase transfer of $\mathrm{N}$ from white clover to grass (or vice versa). The higher $\mathrm{N}$ yield and lower enrichment of mycorrhizal than non-mycorrhizal clover can be explained by AMF enhancing $\mathrm{N}_{2}$-fixation (Hayman,

Table 3

Experiment 1: DM yield $\left(\mathrm{g} \mathrm{pot}^{-1}\right)$ of receiver shoots in each barrier treatment (mean of inoculation treatments)

\begin{tabular}{|c|c|c|c|c|c|c|}
\hline \multirow[t]{2}{*}{ Species } & \multirow[t]{2}{*}{ Barrier $(\mu \mathrm{m})$} & \multicolumn{5}{|l|}{ Harvest } \\
\hline & & 1 & 2 & 3 & 4 & 5 \\
\hline \multirow[t]{5}{*}{ Clover } & Total & 328 & 273 & 281 & 415 & 757 \\
\hline & 5 & 358 & 610 & 387 & 777 & 1360 \\
\hline & 15 & 420 & 468 & 471 & 840 & 1258 \\
\hline & 60 & 368 & 392 & 269 & 497 & 1035 \\
\hline & None & 505 & 448 & 469 & 622 & 1310 \\
\hline \multirow[t]{5}{*}{ Grass } & Total & 1478 & 463 & 705 & 268 & 737 \\
\hline & 5 & 518 & 540 & 456 & 168 & 448 \\
\hline & 15 & 723 & 463 & 705 & 268 & 737 \\
\hline & 60 & 930 & 447 & 534 & 285 & 715 \\
\hline & None & 888 & 448 & 713 & 297 & 778 \\
\hline Species & SEM & $36.0^{* * *}$ & 49.2 & $1.57^{* *}$ & $31.7^{* * *}$ & $54.1^{* * *}$ \\
\hline Barrier & SEM & $57.0^{* * *}$ & 77.8 & 2.48 & 50.1 & 85.5 \\
\hline Species $\times$ Barrier & SEM & $80.6^{* * *}$ & 110.0 & 3.51 & $70.9^{* *}$ & 120.9 \\
\hline
\end{tabular}


Table 4

Experiment 1: nitrogen concentration $\left(\mathrm{g} \mathrm{kg}^{-1}\right)$ in herbage in each barrier treatment (mean of inoculation treatments) in receiver plant shoots

\begin{tabular}{|c|c|c|c|c|c|c|}
\hline \multirow[t]{2}{*}{ Species } & \multirow[t]{2}{*}{ Barrier $(\mu \mathrm{m})$} & \multicolumn{5}{|l|}{ Harvest } \\
\hline & & 1 & 2 & 3 & 4 & 5 \\
\hline \multirow[t]{5}{*}{ Clover } & Total & 22.2 & 37.4 & 37.3 & 33.4 & 23.8 \\
\hline & 5 & 24.4 & 39.9 & 38.0 & 31.1 & 23.1 \\
\hline & 15 & 24.8 & 37.9 & 38.9 & 30.3 & 24.4 \\
\hline & 60 & 23.5 & 34.7 & 36.9 & 28.5 & 21.5 \\
\hline & None & 23.7 & 38.0 & 39.4 & 31.9 & 21.7 \\
\hline \multirow[t]{5}{*}{ Grass } & Total & 15.1 & 14.6 & 16.2 & 12.3 & 18.4 \\
\hline & 5 & 13.7 & 15.7 & 17.2 & 12.5 & 18.0 \\
\hline & 15 & 15.9 & 14.6 & 16.2 & 12.3 & 18.4 \\
\hline & 60 & 13.2 & 14.0 & 16.6 & 12.7 & 18.5 \\
\hline & None & 14.8 & 14.7 & 16.7 & 11.9 & 17.3 \\
\hline Species & SEM & $0.94^{* * *}$ & $0.50^{* * *}$ & $0.49^{* * *}$ & $0.45^{* * *}$ & $0.57^{* * *}$ \\
\hline Barrier & SEM & 1.49 & 0.79 & 0.78 & 0.71 & 0.90 \\
\hline Species $\times$ Barrier & SEM & 2.10 & 1.11 & 1.10 & 1.01 & 1.27 \\
\hline
\end{tabular}

Table 5

Experiment 1: at. $\%{ }^{15} \mathrm{~N}$ excess in herbage in each barrier treatment (mean of inoculation treatments) in receiver plant shoots

\begin{tabular}{|c|c|c|c|c|c|c|}
\hline \multirow[t]{2}{*}{ Species } & \multirow[t]{2}{*}{ Barrier $(\mu \mathrm{m})$} & \multicolumn{5}{|l|}{ Harvest } \\
\hline & & 1 & 2 & 3 & 4 & 5 \\
\hline \multirow[t]{5}{*}{ Clover } & Total & 3.21 & 0.13 & 0.08 & 0.03 & 0.21 \\
\hline & 5 & 2.95 & 0.06 & 0.15 & 0.02 & 0.08 \\
\hline & 15 & 3.50 & 0.11 & 0.08 & 0.02 & 0.10 \\
\hline & 60 & 3.60 & 0.10 & 0.10 & 0.02 & 0.23 \\
\hline & None & 3.68 & 0.05 & 0.05 & 0.02 & 0.12 \\
\hline \multirow[t]{5}{*}{ Grass } & Total & 1.18 & 0.33 & 1.00 & 1.07 & 1.59 \\
\hline & 5 & 1.84 & 0.14 & 0.23 & 0.49 & 0.77 \\
\hline & 15 & 2.22 & 0.69 & 0.25 & 0.41 & 0.86 \\
\hline & 60 & 1.23 & 0.23 & 0.86 & 1.40 & 1.81 \\
\hline & None & 1.70 & 0.39 & 0.81 & 1.20 & 1.38 \\
\hline Species & SEM & $0.320^{* *}$ & 0.084 & $0.060^{* * *}$ & $0.056^{* * *}$ & $0.040^{* * *}$ \\
\hline Barrier & SEM & 0.506 & 0.133 & $0.095^{*}$ & $0.088^{* * *}$ & $0.063^{* * *}$ \\
\hline Species $\times$ Barrier & SEM & 0.716 & 0.189 & $0.134^{* *}$ & $0.125^{* * *}$ & $0.089^{* * *}$ \\
\hline
\end{tabular}

1987). The higher infection rate of white clover roots than those of grass supports the proposition that clover roots are more mycotrophic than grass roots (Haynes, 1980). Taking the $5 \mu \mathrm{m}$ barrier as a base on which to judge transfer of $\mathrm{N}$ in other treatments, about $30 \%$ more $\mathrm{N}$ was transferred in the $60 \mu \mathrm{m}$ than the $5 \mu \mathrm{m}$ treatment. However, this occurred irrespective of the presence of AMF.

In the study of Haystead et al. (1988) in which they concluded that direct hyphal transfer of $\mathrm{N}$ between clover and grass occurred, a $60-\mu \mathrm{m}$ mesh barrier was used to allow hyphae, but not roots, to pass. However, as found in Experiment 2 in this study, fine roots of grass can penetrate a $60-\mu \mathrm{m}$ mesh. Hence it is possible that the greater amount of clover-derived $\mathrm{N}$ in grass separated from clover by the $60-\mu \mathrm{m}$ mesh barrier in the mycorrhizal than the non-mycorrhizal treatment could have been due to more $\mathrm{N}$ being available to the fine roots of grass which had penetrated the barrier in the clover rhizosphere in the inoculated treatment.

The absence of AMF-stimulated transfer in the 60 $\mu \mathrm{m}$ treatment in this study may have been due to the high $\mathrm{N}$ transfer in the non-mycorrhizal treatment masking any additional transfer which may have resulted from the greater root mass in the AMF treatment. Closeness of contact between the root systems of the legume and grass has been shown by Hamel et al. (1991) (working with soybean and maize) to be more important than AMF presence in $\mathrm{N}$ transfer.

The nutrient status of the receiver relative to that of the donor has been considered to be a factor in determining the degree of hyphal mediated $\mathrm{N}$ transfer (Bethlenfalvay et al., 1991) although Frey and Schüepp (1992) recorded some AMF-mediated N transfer 
Table 6

Experiment 2: details of penetration of pores in mesh barriers by roots of clover and grass

\begin{tabular}{|c|c|c|c|c|c|}
\hline \multirow[t]{2}{*}{ Barrier $(\mu \mathrm{m})$} & \multirow[t]{2}{*}{ Species } & \multirow{2}{*}{$\begin{array}{l}\text { Penetration of } \\
\text { mesh }\end{array}$} & \multirow{2}{*}{$\begin{array}{l}\text { Mean root } \\
\text { length }\end{array}$} & \multicolumn{2}{|l|}{ Root diameter $(\mu \mathrm{m})$} \\
\hline & & & & Prior to penetration & After penetration \\
\hline \multirow[t]{2}{*}{5} & Clover & No & 0 & 0 & 0 \\
\hline & Grass & No & 0 & 0 & 0 \\
\hline \multirow[t]{2}{*}{15} & Clover & No & 0 & 0 & 0 \\
\hline & Grass & No & 0 & 0 & 0 \\
\hline \multirow[t]{2}{*}{35} & Clover & No & 0 & 0 & 0 \\
\hline & Grass & Yes & 2 & 230 & 84 \\
\hline \multirow[t]{2}{*}{60} & Clover & No & 0 & 0 & 0 \\
\hline & Grass & Yes & 84 & 274 & 128 \\
\hline
\end{tabular}

between berseem and maize even when maize was not apparently N-deficient (Barber and Martin, 1976). As Experiment 1 progressed there was an indication that the smallest mesh size resulted in the lowest grass yield, suggesting that grass was relying on $\mathrm{N}$ from the clover donor. Despite that, and taking account of the fact that roots were well infected with AMF, mycorrhizal transfer was not apparent.

Frey and Schüepp (1992) have used a mesh of pore size $0.45 \mu \mathrm{m}$ as a barrier to external hyphae of AMF. In this study it was considered that such a small pore size would be a hindrance to mass flow and diffusion as strong suction is required when using such membranes for filtration. Rogers (1993) found no evidence of external hyphae passing from inoculated roots through a membrane of $5 \mu \mathrm{m}$ pore size when they were growing adjacent to the barrier. We are therefore convinced that the $5-\mu \mathrm{m}$ pore size was an effective barrier for hyphae.

${ }^{14} \mathrm{C}$ was found in the grass roots in Experiment 3, suggesting that some form of transfer of carbon had occurred between the two root systems. It is well known that $\mathrm{C}$ is transported from shoots of AMF-infected plants into the hyphae, e.g. in cucumber plants (Jakobsen and Rosendahl, 1990). Although there was no indication from Experiment 3 of the root systems, by microscopy or from the autoradiographs that hyphal links had been involved in the transfer, it is possible that AMF external hyphae may have translocated ${ }^{14} \mathrm{C}$ from the donor plants and released it into the rhizosphere of the receivers. Alternatively, roots may have released carbon compounds during growth (Barber and Martin, 1976; Martin, 1977) and white clover roots turn over much faster than those of grass (Laidlaw et al., 1996). Therefore the ${ }^{14} \mathrm{C}$ in grass roots may have resulted from uptake of some of this released carbon.

Further evidence against the implication of hyphal links in $\mathrm{N}$ transfer between clover and grass is the existence of partial ecological specificity between AMF and their host, as has been found for AMF populations which infect white clover and perennial ryegrass (Rogers et al., 1994; Zhu et al., 2000). In conclusion, this study suggests that $\mathrm{N}$ transfer between white clover and perennial ryegrass is unlikely to occur through AMF hyphal links in agricultural soils where the opportunities for alternative routes of transfer are likely to be well developed.

\section{Acknowledgements}

J.B. Rogers is grateful to the Ministry of Agriculture, Fisheries and Food for a postgraduate studentship.

\section{References}

Barber, D.A., Martin, J.K., 1976. The release of organic substances by cereal roots in soil. New Phytol. 76, 69-90.

Barea, J.M., El-Atrach, F., Azcon, R., 1989. Mycorrhiza and phosphate interactions as affecting plant development, $\mathrm{N}_{2}$ fixation, $\mathrm{N}$-transfer and $\mathrm{N}$-uptake from soil in legume-grass mixtures by using a ${ }^{15} \mathrm{~N}$ dilution technique. Soil Biol. Biochem. 21, 581-589.

Bethlenfalvay, G.J., Reye-Solis, M.G., Camel, S.K., FerreraCerrato, R., 1991. Nutrient transfer between soybean and maize connected by a common mycorrhizal mycelium. Physiol. Pl. 82, 423-432.

Butler, G.W., Greenwood, R.M., Soper, K., 1959. Effects of shading and defoliation on the turnover of root and nodule tissue of plants of Trifolium repens, Trifolium pratense and Lotus uliginosus. N.Z. J. Agri. Res. 2, 415-426.

Dart, P.J., Pate, J.S., 1959. Nodulation studies in legumes 3. The effects of delaying inoculation on the seedling symbiosis of barrel medic Medicago tribuloides. Desr. Austr. J. Biol. Sci. 12, 427-444.

Dubach, M., Russelle, M.P., 1994. Forage legumes roots and nodules and their role in nitrogen transfer. Agron. J. 86, 259-266.

Frey, B., Schüepp, H., 1992. Transfer of symbiotically fixed nitrogen from berseem (Trifolium alexandrinum $\mathrm{L}$.) to maize via vesicular-arbuscular mycorrhizal hyphae. New Phytol. $122,447-454$.

Frey, B., Schüepp, H., 1993. A role of vesicular-arbuscular (VA) mycorrhizal fungi in facilitating interplant nitrogen transfer. Soil Biol. Biochem. 25, 651-658. 
Hamel, C., Barrentes-Cartin, U., Furlan, V., Smith, D.L., 1991. Endomycorrhizal fungi in nitrogen transfer from soybean to maize. Plant and Soil 138, 33-40.

Haynes, R.J., 1980. Competitive aspects of the grass-legume association. Adv. Agron. 33, 227-261.

Hayman, D.S., 1987. VA mycorrhizas in field crop systems. In: Safir, G.R. (Ed.), Ecophysiology of VAM Plants. CRC Press, Boca Raton, pp. 172-192.

Haystead, A., Malajczuk, N., Grove, T.S., 1988. Underground transfer of nitrogen between pasture plants infected with vesicular arbuscular mycorrhizal fungi. New Phytol. 108, $417-423$.

Ikram, A., Jensen, E.S., Jakobsen, I., 1994. No significant transfer of $\mathrm{N}$ and $\mathrm{P}$ from Pueraria phaseoloides to Hevea brasiliensis via hyphal links of arbuscular mycorrhiza. Soil Biol. Biochem. 26, 1541-1547.

Jakobsen, I., Rosendahl, L., 1990. Carbon flow into soil and external hyphae from roots of mycorrhizal cucumber plants. New Phytol. 115, 77-83.

Laidlaw, A.S., Christie, P., Lee, H.W., 1996. Effect of white clover cultivar on apparent transfer of nitrogen from clover to grass and estimation of relative turnover rates of nitrogen in roots. Plant and Soil 179, 243-253.

Martin, J.K., 1977. Factors influencing the loss of organic carbon from wheat roots. Soil Biol. Biochem. 9, 1-7.

Phillips, J.M., Hayman, D.S., 1970. Improved procedures for clearing roots and staining parasitic and vesicular-arbuscular mycorrhizal fungi for rapid assessment of infection. Trans. Br. Mycol. Soc. 55, pp. 158-160.

Rogers, J.B., 1993. Investigation of the role of mycorrhizas in the transfer of nitrogen from white clover to grass. $\mathrm{PhD}$ Thesis, The Queen's University of Belfast, $216 \mathrm{pp}$.

Rogers, J.B., Christie, P., Laidlaw, A.S., 1994. Some evidence for host specificity in arbuscular mycorrhizas. Pedosphere 4, 377-381.

Ta, T.C., McDowall, F.D.H., Faris, M.A., 1986. Excretion of assimilated $\mathrm{N}$ fixed by nodules of alfalfa (Medicago sativa). Can. J. Bot. 64, 2063-2067.

Zhu, Y.G., Laidlaw, A.S., Christie, P., Hammond, M.E.R., 2000. Ecological specificity of arbuscular mycorrhiza fungi in perennial ryegrass-white clover pasture. Agriculture Ecosystems and Environment 77, 211-218. 